\title{
MINERAL RESOURCES OF COSTA RICA
}

\author{
Anónimo \\ Transcrito por: \\ Siegfried Kussmaul
}

\section{Escuela Centroamericana de Geología, Universidad de Costa Rica}

\author{
Documento original tomado de: The Mining Journal (abstracted mainly from \\ the Revista Económica); August 22, 1914; págs. 767-768
}

The history of Costa Rica [Fig. 1] mining operations reaches back into colonial times. Some of the largest gold mines have been worked in a primitive way with success for several centuries, and the mineral treasures brought up to the light of day by the old Spanish gold seekers are said to have been almost fabulous. One of the richest gold mines called Tisingall, had to be abandoned because of the hostility of the native Indians ; the mine itself was then completely destroyed by them, and the locality closes up by changing the course of the neighbouring streams. After quelling the uprising it was impossible for the Spaniards to locate the rich mine again. It is thought at present that this mine lies hidden in the bed of one of the larger streams, and that a number of other mines worked with success by Indians and Spaniards now lie hidden under heavy forest growths.
But enough of the past! This progressive country with its varied national wealth, which the Spaniards named "Costa Rica", with good reason now arouses a lively interest in other countries. Distinguishing itself for a long time past from the other countries of Central America to its advantage with its stable and responsible Government, this still scantily-populated republic offers opportunities for investment of foreign capital equalled by few countries. It is abundant and diversified mineral wealth, which is coming more and more to the front, is already attracting the attention of large capitalists to-day. Abundant forests, unlimited hydraulic power, some means of local transportation, though still too few, are favourable conditions for successful working of the diversified deposits of useful minerals. The geological picture of Costa Rica is bright and rich. Aside 
from numerous places where free gold and silver occur, mention may be made of copper, wolfram, magnesia, nickel, iron, cinnabar, and coal. In connexion with these minerals, kaolin of the best quality, cement, alumina, and ochre for colouring purposes are found.

The rocks of Costa Rica are generally of volcanic origin, and formed of diorites, porphyries and basalts. Black boulders are found in a good many places. The climate of the mining region is pleasant and healthful. On the mountain of Aguacate the temperature almost always reaches 72 degs. F. The waters are pure and abundant, and can be utilised in a good many of the mines as motive power. The Albangares river, which traverses the mining district of the same name, gives a force of 850 horse-power. There is excellent building timber, which can be obtained and used in the mining works at moderate process. The mining zone of Cost Rica, $8,800 \mathrm{ft}$. on the average above the level of the sea, is found on the Pacific slope; it extends from north-west to south-west, and includes the following three districts: (1) the Albangares mines ; (2) the mines of Montes de Oro; (3) the mines of Monte de Aguacate.

The Albangares Gold Fields Company, working with a capital of $\$ 2,500,000$, is located eighteen leagues from Puerto Iglesias (Nota: hoy conocido como Manzanillo), with a good waggon road. From this locality to Punta Arenas (on the Pacific Ocean) is a distance of twenty leagues. The situation is favourable for the exportation of ores and the importation of the machinery necessary for the works. The company now has a milling capacity of 10,000 tons a month. The mine of Tres Amigos is worked at present by the company of the Albangares Gold Fields Mining Syndicate. The Boston mine belongs to the Costa Rica Esperanza Mining Company, and is being worked at present. The Albangares mines extend over about 150 square leagues of territory, and are situated in the province of Guanacaste. According to a report to the shareholders the Albangares mines are producing some $\$ 12,000$ (U.S. Money) per month. They have considerably increased the amount produced lately by using better machinery and more modern methods for the extraction

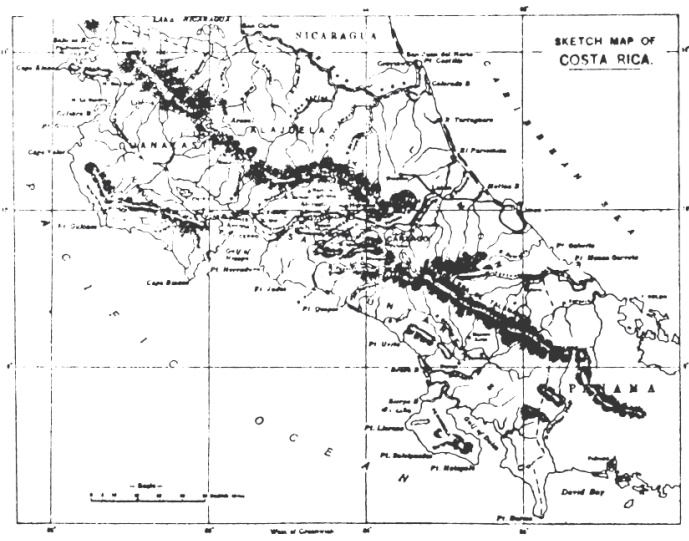

Fig. 1: Mapa de Costa Rica (tomado de: The Mining Journal, 1914). La figura se localiza en el repositorio correspondiente a este artículo.

and separation of the metals. In the mining camps under discussion modern living houses are found, cleanliness, electric lighting, good water, modern machinery-in short, all that could be expected of a great enterprise working a deposit of the richness of that of Albangares.

Let us take up now the mines of the Monte del Aguacate district, which are situated in the province of Alajuela, between 10 degs. $12 \mathrm{~min}$. 30 secs. North latitude and 84 degs. 28 mins. 30 secs. West from the meridian of Greenwich, 1,800 ft. above sea level. The railroad from San José to Punta Arenas (Pacific Ocean) passes within two leagues of the mines at a place called Río Concepción. The mines of Monte del Aguacate were discovered in 1815, and it is estimated that from 1820 to 1845 they produced a quantity of gold and silver worth about 8,000,000 American dollars. With perfected machinery $\$ 2,000,000$ more would have been taken out. The Aguacate mining district is composed of five groups, as follows: Aguacate, Sagrada Familia, Los Castros, Quebrada Honda, El Porvenir. The Sagrada Familia is situated in the canton of San Mateo, Province of Alajuela ; it belongs to W.J. Ford \& Company. Work has been resumed there since 1901. Los Castros is located in the same canton. Mr. Frederico Tinoco is its representative. This mine was discovered in 1822 by Nicolás and Pío Castro. Quebrada Honda, situated in San Mateo, is the property of Mr. Demetrio Iglesias. El Porvenir, along the Machuca river, not far from 
San Mateo, produces gold and silver ; it belongs to the Río Grande Company, and was claimed in 1900 by Mr. Gorenaga y García. Monte del Aguacate has for its proprietors Federico Tinoco \& Company.

The principal veins of this district are as follows: Main lode has two parallel veins, called Veta Colorado and Veta Blanca; La Minita, laid claim to in 1826 and worked with success till 1862 ; Guapinol, discovered in 1828, and claimed by Oreamuno: La Balsa, claimed in 1825 . The first money of the country was coined with gold from this mine. At La Ciguëña work was abandoned in 1875. El Fuego is situated between Guapinol and La Cigüeña. Mr. Eusebio's mine must also be mentioned in concluding.

It remains to say a few words of the third and last district, that of Montes de Oro, composed of the following mines: La Trinidad, at present the property of an English company, the manager of which is Mr. W.J. Ford, it is situated at San Mateo, province of Alajuela; La Unión, situated at Montes de Oro, in the section of Punta Arenas, the property of the Costa Rica Unión Mining Company, of San Francisco, California, it has not been worked for some years ; La Macacona, worked about thirty years ago by a native company with a small capital, it was bought in 1899 by R.A. Crespi \& Company ; La Bella Vista, belonging to the Thrayer Mining \& Milling Company, situated in the district of Miramar, in the Territory of Punta Arenas.

Independent of these groups of mines, there are others which have been worked or where work is now going on. We will mention especially the following : Las Cañas Syndicate Company has twenty-seven properties, among which is $\mathrm{La}$ Esperanza ; Guanacaste possesses especially the Gier Vein and the Pequeña Oracu ; the works of these two syndicates have not yet been installed, but the works have been planned on a large scale. La Mina Santiago Sur, situated at San Ramón, Province of Alajuela, was discovered about thirty years ago by Félix Castro and Gregorio Morales ; it belongs to-day to an American company, which laid claim to it some years ago as an abandoned mine. Peña Grande, also situated at San Ramón, was worked by Mr. F.M. Iglesias from 1864 to
1875 ; San Gerardo, eight kilometres from the city of San Ramón, worked by Mr. R. Acosta in 1879 ; the Barranca company, canton of San Ramón, is the owner of Los Hervideros and of Rancho de los Chanchos, situated on both sides of the Barranca river, about ten leagues from the city of Esparta. The mine of Los Hervideros produces gold and silver, and is being worked. Miramar, in the district of Montes de Oro, territory of Punta Arenas, belongs to the Montezuma company ; it is auriferous and very rich. Santa Ana, in the canton of the same name, province of San José, property of Mr. Louis Pullinger, is being worked. A mine of gold, silver and copper at Santa Ana has been laid claim to recently by Mr. D. Herbert Ross.

It is probable that, aside from the regions already mentioned, there is gold in good quantity on the southern slopes on the mountains of Guatuose and Miravalles, the rocks of which are of feldspar, porphyry and basalt, and veins of gold have been discovered in the mountains of Buena Vista, at Talamanca, in the placers of the Duedi river, at Guacimal, at San Ramón and in other localities in the country, especially if the long list of entries made for mining claims in the past twenty years is taken into consideration.

An examination of the claims filed show that there are a great many other places in the country that have concealed in them minerals of value, such as gold, silver, copper, zinc, mercury, iron, lead, marble, onyx, lignites, petroleum, \&c., all of them mines that need only capital and experience to be worked. It is to be noted that the gold ores extracted generally contain little silver, but there are said to be rich deposits of this latter metal in the country.

The workers in the mines are good, intelligent workers ; their wages are not high, amounting to about three colons a day, or $\$ 1.35$ in American money ; ordinary labour is paid for at about half this rate.

Mr. Roberto A. Crespi, manager of the mines of the Costa Rica Exploration Company and one of the leading stockholders, is an expert on the subject, and a large part of the progress of the mining industry in Costa Rica is due to him. ExPresident Iglesias, another eminent miner, is the 
owner of the greater part of the mines of Aguacate mountain. A great many important personages and capitalists of the country are interested financially in the mining enterprises, and some believe that, inside of ten years or so, the working of mines will be the principal industry of Costa Rica.

The Colburn Mines \& Development Company, of Oakland, California, with a capital of $\$ 100,000$, has opened an office in Costa Rica, with the purpose of engaging in mining operations.

The mining laws are framed in a very liberal spirit. The Government has always observed a protecting and friendly attitude towards mining enterprises. In the time of General Tomás Guardia, a law was passed exempting from military service the men working in the mines.

The Albangares Mining Syndicate has secured for itself, through contracts with the Government, concessions and advantages which the nation would doubtless grant to similar enterprises, which, with well-defined purposes and with a capital deemed sufficient by the Government, might propose to organise companies for working the mines, seeing that, in granting these conditions, it had no other object in view but protecting and stimulating the development of the untouched national wealth. One of the great concessions obtained by the Albangares Syndicate is that all the mining veins existing on the lands of the company and on those it may acquire afterwards are its property, provided that it does not let more than three consecutive years pass without working one or more of these veins. The other advantage consists in the exemption from all national taxes that may be provided for on its properties or on the products of the mines, and on all the other works and accessory operations related to the working of said mines. The length of time for which this privilege or this concession holds good is fifty years. The machinery, tools and explosives intended for the mines in general can be imported free of Customs duties. The syndicate pays to the Government, according to the terms of the contract, a direct tax of 1 per cent. per year on the gross product of the enterprise during the first twenty-five years of the contract, and 2 per cent. on the same gross product during the following twenty-five years.

The development of mineral production in Costa Rica is best illustrated by the following tabulated summary : -- [Table 1]

\section{PETROLEUM}

A contract was made in October 1913 between the Government of Costa Rica and a British firm, presumably Messrs. Pearson \& Sons, whose representatives were reported seeking to negotiate a contract for the exploration and development of any petroleum beds found. This contract was not ratified by Congress ; in consequence of the attention thus drawn to the possibilities of the discovery of petroleum, a large number of denouncements of petroleum rights have been filed by speculators, but up to date no serious exploration of development work has been attempted.

Table 1

Development of mineral production in Costa Rica

\begin{tabular}{ccccccc}
\hline & 1907 & 1908 & 1909 & 1910 & 1911 & 1912 \\
\hline & \multicolumn{7}{c}{ (In thousands of dollars, U.S. gold.) } \\
\hline Gold bars & 239,861 & 591,957 & 564,328 & 466,453 & 729,312 & 399,953 \\
Silver bars & 181,159 & 81,246 & 228,717 & 344,936 & 441,558 & 351,683 \\
Rich ores & -- & -- & -- & 48,670 & 28,837 & 61,901 \\
\hline
\end{tabular}




\section{REVISTA GEOLÓGICA DE AMÉRICA CENTRAL GUÍA PARA LOS AUTORES}

\section{La REVISTA GEOLÓGICA DE AMÉRICA} CENTRAL (RGAC) es una publicación científica oficial de la Universidad de Costa Rica. Su objetivo es difundir la investigación geológica y geocientífica de índole básica o aplicada, realizada en América Central, El Caribe o de interés general en esta área. La RGAC publica los siguientes tipos de artículos:

a) trabajos originales e inéditos de investigación tanto académica como tecnológica,

b) notas técnicas y científicas,

c) mapas geológicos y sus guías,

d) resúmenes de tesis,

e) reseñas de libros,

f) réplicas sobre publicaciones en esta Revista,

g) comentarios sobre actividades de interés para el campo geológico.

Los artículos sometidos deberán estar escritos en español o inglés, y ser enviados por vía electrónica en formato Word al director y editor a las siguientes direcciones electrónicas:

pdenyer@geologia.ucr.ac.cr

katomirodriguez@yahoo.com

y en impreso por duplicado a la siguiente dirección:

\author{
Revista Geológica de América Central \\ Escuela Centroamericana de Geología \\ Apdo. 214-2060 Universidad de Costa Rica \\ San José, Costa Rica
}

Los artículos serán revisados por al menos un árbitro externo y el Consejo Editorial, el cual decidirá sobre su publicación. El tema del trabajo sometido a publicación es responsabilidad exclusiva del autor o autores. Los artículos que no se ajustan al formato y temática serán devueltos. Los autores deberán someterse a las siguientes normas:

Texto: Se solicita utilizar letra Times New Roman 12. Se inicia con el título en negrita, seguida por los autores con nombre, inicial del segundo nombre y apellido o apellidos si es de su gusto, separados entre sí por comas. Cuando pertenecen a una sola institución, el detalle de su afiliación aparecerá a renglón seguido, y el correo electrónico del autor principal o correspondiente, o de todos ellos, si se desea. Debe señalarse con un asterisco al autor correspondiente para comunicación. Si pertenecen a varias instituciones o departamentos, se indicarán con numeraciones en superíndice siguiendo al nombre, y a renglón seguido las correspondientes afiliaciones. Debe contener un abstract en inglés y un resumen en español con un máximo de 150 palabras cada uno, equivalentes en su contenido, a espacio simple, así como 5 a 7 palabras clave separadas por comas, y sus equivalentes key words. El cuerpo del artículo debe estar a doble espacio en papel tamaño carta. Los capítulos son titulados en mayúsculas, negrilla y centrados, los subcapítulos en negrilla minúsculas con alineación izquierda, y los subsubcapítulos en negrilla, cursiva y alineación izquierda. Si se incluyen agradecimientos deben ir al final del artículo previo a las referencias. Las referencias aparecen de último capítulo, excepto 
cuando hayan apéndices o anexos. La guía para las referencias se da en un capítulo aparte en este mismo número.

Los trabajos de investigación deben tener una extensión máxima de 40 páginas, mientras que las notas técnicas y científicas, un máximo de 6 páginas. Las páginas deben ir numeradas en el extremo inferior derecho.

Abreviaturas, acrónimos y siglas: Deberán detallarse las palabras completas la primera vez que se usan en el texto, excepto aquellas de amplio uso común (p.ej.: p.ej.).

Cuadros: Se citan dentro del texto donde corresponda, pero se presentan al final, en páginas consecutivas aparte. Se debe utilizar el mismo tipo de letra, mas pueden reducirse si la información cubre muchas o amplias columnas, sin embargo nunca menor a 7. El cuadro no debe contener líneas de borde, excepto los bordes superior e inferior de la primera línea y el borde inferior de la última línea. Se debe indicar el número de cuadro y a renglón seguido su explicación, ambos centrados en la parte superior antecedente al cuadro.

Figuras: Incluye figuras en líneas, fotografías, croquis y mapas. Se citan dentro del texto donde corresponda, pero se presentan al final, en páginas consecutivas aparte. Todas deben ser en blanco y negro numeradas consecutivamente. Los tamaños máximos son de $20 \mathrm{~cm}$ de alto por $14 \mathrm{~cm}$ de ancho para doble columna, y de $20 \mathrm{~cm}$ de alto por $7 \mathrm{~cm}$ de ancho para una columna. Las escalas deben estar en forma gráfica. La explicación de cada figura se debe incluir centrada bajo la figura correspondiente. Para la presentación final del artículo en digital se sugiere utilizar formato ai o cdr para las figuras en líneas, mapas y croquis y formato tiff para las fotografías con una resolución mínima de 300 ppp (puntos por pulgada o dpi), al tamaño estipulado arriba. Para la versión final de un artículo aceptado no son aceptables figuras insertadas en Word o algún otro procesador de texto. Deben tener un formato de dibujo.

Unidades: Debe usarse sin excepción el Sistema Métrico Decimal (para consultas detalladas se sugiere visitar el cibersitio http://phy- sicstoday.org/guide/metric.pdf). En general no llevan punto y casi todas son en minúsculas (p.ej., las medidas de longitud $\mathrm{km}, \mathrm{m}, \mathrm{cm}, \mathrm{mm}$; las de tiempo h, min, s; las de peso $\mathrm{kg}, \mathrm{g}$, mg; las de tiempo geológico son ka para miles de años y $\mathrm{Ma}$ para millones de años). Los decimales deben usar coma y los miles a partir de cinco cifras, espacios separando grupos de tres dígitos. En inglés sí se usa el punto decimal, pero la misma convención para los miles.

Uso de mayúsculas: Se usan las mismas convenciones que en la ortografía española estándar (consultas respecto al uso detallado se pueden hacer en el cibersitio http://www.rae. es/rae/gestores/gespub000015.nsf/(voanexos)/ arch7E8694F9D6446133C12571640039A189/ \$FILE/Ortografia.pdf). En los casos de nuestro interés, los nombres geográficos, geológicos y estratigráficos propios, deben ir con mayúscula, mas no los genéricos o adjetivales. De tal manera, se escriben con mayúscula "Formación San Miguel", "Complejo de Nicoya", "Cretácico", "Santa Elena", pero no usan mayúscula "las formaciones San Miguel y Coris", "los complejos ígneos del Pacífico", "los fósiles cretácicos". Los nombres geográficos de ríos, ciudades, provincias, cantones, golfos, penínsulas, montañas, volcanes y otros, solo usan mayúscula los nombres propios, como p.ej. río Barranca, ciudad de San José, provincia de Puntarenas, cordillera de Talamanca, volcán Poás, isla Chira. Si el sustantivo geográfico es parte del nombre propio, usa mayúscula, como los casos Río Grande, Puerto Viejo, Ciudad Neilly.

Puntos cardinales: Se pueden usar abreviados con mayúscula (N, S, E, W; SW, NE) o la palabra completa en minúscula (sur, noreste, noroeste).

Artículos aceptados y su publicación: Una vez que los árbitros y el Comité Editorial hayan revisado los artículos, estos serán remitidos de vuelta a los autores para su arreglo y remisión final. Este envío final será exclusivamente en forma digital, con el texto siguiendo las mismas normas establecidas anteriormente. Las figuras deberán remitirse en formatos tiff, jpg, cdr, gif, bmp, ai o psd, con el tamaño 
correcto de publicación con una resolución mínima de 300 ppp, según lo estipulado anteriormente. Una vez recibido por los editores en su versión final, estos decidirán sobre su aceptación y notificarán a los autores. Estos deberán revisar las galeras de manera digital cuando se les envíe, en un plazo no mayor a cinco días naturales. Una vez publicado el artículo, el resumen aparecerá de manera digital en http://www.geologia.ucr. ac.cr/revista-geol.htm. El autor principal o correspondiente recibirá gratuitamente un ejemplar de la revista y diez separatas del artículo. 